\title{
Pemberdayaan Mantan Mucikari melalui Pemanfaatan Sampah Organik dan Non Organik pada Eks Lokalisasi Padang Pasir Rogojampi Banyuwangi
}

\author{
Moh. Harun Al Rosid, Maskur, Mamlukhah., Nurul Inayah, \\ IAIDA Darussalam \\ inayahsyaikhoni@yahoo.co.id
}

\begin{abstract}
ABSTRAKSI
Dampak Penutupan Lokalisasi di Kabupaten Banyuwangi adalah : Menurunnya tamu mempengaruhi penghasilan warga eks lokalisasi dan berdampak menurunnya penghasilan dari warga yang menggantungkan hidup pada lokalisasi. Warga yang menggantungkan hidup pada lokalisasi selain PSK (Pekerja Seks Komersial) juga ada mucikari. Dan setelah penutupan lokalisasi mantan mucikari yang berada di eks lokalisasi padang pasir Rogojampi tidak mampu lagi berpenghasilan seperti sebelum penutupan lokalisasi. Pada akhirnya sebagian dari mantan mucikari mulai beralih profesi, ada yang mencoba untuk berdagang, mengumpulkan sampah dan menjadi buruh pemilah sampah. Dikarenakan disekitar lokalisasi banyak warga yang menjadi pengumpul sampah maka untuk menambah nilai sampah perlu dilakukan pemberdayaan mantan mucikari melalui pemanfaatan sampah organik dan non organik pada eks lokalisasi Padang Pasir Rogojampi Banyuwangi sebagai upaya untuk meningkatkan penghasilan mantan mucikari yang telah mengalami penurunan penghasilan setelah penutupan lokalisasi. Dari hasil temuan adalah : Strategi yang dilakukan untuk pemberdayaan mantan mucikari tersebut adalah dengan melakukan pelatihan pembuatan kompos dari sampah organik dan membuat tas, bros, dan gantungan kunci dari sampah non organik. Stakeholder yang terlibat dalam pemberdayaan mantan mucikari tersebut adalah Perangkat desa Karangbendo, perangkat kecamatan Rogojampi dan BPM PD kabupaten Banyuwangi.
\end{abstract}

Kata Kunci : pemberdayaan, mantan mucikari, sampah organik, sampah nonorganik

\section{PENDAHULUAN}

\section{A. Latar Belakang}

Dengan diterbitkannya Peraturan Bupati Banyuwangi bernomor 88 Tahun 2011 tentang Pencegahan dan Penanggulangan Penyebarluasan Pekerja Seks Komersial (PSK) di Kabupaten Banyuwangi, pemerintah kabupaten Banyuwangi segera melakukan penutupan di 11 lokalisasi yang ada. Dan Pendataan pada tahun 2011 jumlah mucikari 223 dan PSK sejumlah 616 yang ada di Kabupaten Banyuwangi, dan saat ini semua lokalisasi yang ada di kabupaten Banyuwangi telah ditutup. ${ }^{1}$

Dari survey yang telah dilakukan ditemukan bahwa Dampak Negatif Penutupan Lokalisasi di Kabupaten Banyuwangi adalah : Menurunnya tamu mempengaruhi penghasilan warga eks

${ }^{1}$ Bappeda, 2014, Capaian Kinerja \& Arah Kebijakan Pembangunan Daerah Kabupaten Banyuwangi 
lokalisasi dan berdampak menurunnya penghasilan dari warga yang menggantungkan hidup pada lokalisasi. Dan dikarenakan lokalisasi yang telah ditutup masih secara rutin di razia oleh satpol PP maka Transaksi prostitusi dilakukan sembunyi-sembunyi pada eks lokalisasi. ${ }^{2}$

Sedangkan dampak lain dari penutupan lokalisasi di Kabupaten Banyuwangi diantaranya adalah : Penutupan Lokalisasi mampu mengurangi transaksi prostitusi dan miras. Dan dibeberapa lokalisasi yang telah ditutup warganya telah mampu berwiraswasta dan beralih profesi namun tidak secara keseluruhan. Secara sporadik pemerintah daerah telah melakukan pelatihan ketrampilan serta memberikan dana pesangon sebesar Rp. 5.000.000,- untuk mantan PSK dan Rp. 6.800.000,- untuk mucikari.

Di beberapa eks lokalisasi warganya ada yang telah mampu untuk memanfaatkan dana bantuan yang telah diberikan dengan memulai usaha berdagang, berternak, membordir dan ada juga yang menjadi buruh. ${ }^{3}$

Di lokalisasi Padang Pasir saat bertemu dengan Bapak Samsuri 36 tahun yang hanya lulusan SD, menyebutkan bahwa selama ini lokalisasi padang pasir yang sebelum penutupan ditempati oleh $36 \mathrm{KK}$, dimana tidak semua KK yang ada di lokalisasi padang pasir menjadi mucikari, belum pernah pendapatkan bantuan berupa dana maupun pelatihan yang telah diprogramkan oleh pemerintah daerah kabupaten Banyuwangi.

Setelah penutupan lokalisasi mantan mucikari yang berada di eks lokalisasi padang pasir tidak mampu lagi berpenghasilan seperti sebelum penutupan lokalisasi. Kehidupan membutuhkan biaya untuk mampu bertahan, pada akhirnya sebagian dari mantan mucikari mulai beralih profesi, ada yang mencoba untuk berdagang, mengumpulkan sampah dan menjadi buruh pemilah sampah.

Dimana produk tersebut akan lebih bernilai jual, dan mampu dijadikan sebagai sumber penghasilan dengan melalui pemberdayaan mantan mucikari melalui pemanfaatan sampah organik dan nonorganik pada ekslokalisasi padang pasir rogojampi Banyuwangi perlu dilakukan , karena dengan hal ini diharapkan para mantan mucikari akan mampu berdaya dan beralih profesi.

\section{B. Masalah}

Dari gambaran dan uraian di atas dapat dikemukakan pokok permasalahan di atas antara lain :

\footnotetext{
${ }^{2}$ Yudo Prasetyo, 2013, Efektifitas Peraturan Bupati No. 88 Tahun 2011 Implikasinya Terhadap Pencegahan Dan Penanggulangan Penyebarluasan Pekerja Seks Komersial (Psk) Di Kabupaten Banyuwangi”, Skripsi, UNTAG Banyuwangi

${ }^{3}$ ibid
} 
1. Bagaimana pemberdayaan mantan mucikari melalui pemanfaatan sampah organik dan non organik pada eks lokalisasi Padang Pasir Rogojampi Banyuwangi dilaksanakan ?

2. Bagaimana Strategi yang dilakukan untuk pemberdayaan mantan mucikari melalui pemanfaatan sampah organik dan non organik pada eks lokalisasi Padang Pasir Rogojampi Banyuwangi?

3. Siapa saja stakeholder yang terlibat dalam pemberdayaan mantan mucikari melalui pemanfaatan sampah organik dan non organik pada eks lokalisasi Padang Pasir Rogojampi Banyuwangi ?

\section{Tujuan Penelitian}

1. Untuk mengetahui pemberdayaan mantan mucikari melalui pemanfaatan sampah organik dan non organik pada eks lokalisasi Padang Pasir Rogojampi Banyuwangi dilaksanakan?

2. Untuk mengetahui Strategi yang dilakukan untuk pemberdayaan mantan mucikari melalui pemanfaatan sampah organik dan non organik pada eks lokalisasi Padang Pasir Rogojampi Banyuwangi ?

3. Untuk mengetahui Siapa saja stekholder yang terlibat dalam pemberdayaan mantan mucikari melalui pemanfaatan sampah organik dan non organik pada eks lokalisasi Padang Pasir Rogojampi Banyuwangi ?

\section{Manfaat/Urgensi Penelitian}

Pemberdayaan mantan mucikari melalui pemanfaatan sampah organik dan nonorganik pada Ekslokalisasi Padang Pasir Rogojampi Banyuwangi perlu dilakukan karena dengan pemberdayaan ini diharapkan para mantan mucikari akan mampu dan berdaya selanjutnya beralih pada profesi yang lebih terhormat.

\section{E. Batasan, Ruang Lingkup Penelitian}

Agar pembahasan dalam laporan tidak membias maka pembahasan dibatasi hanya pada pemberdayaan mantan mucikari melalui pemanfaatan sampah organik dan nonorganik pada Ekslokalisasi Padang Pasir Rogojampi Banyuwangi.

\section{KERANGKA TEORI}

\section{A. Pemberdayaan Masyarakat}

\section{Pengertian Pemberdayaan Masyarakat}

Pemberdayaan merupakan terjemahan dari bahasa Inggris yaitu empowerment, yang secara harfiah berarti pemberkuasaan. Pemberkuasaan itu sendiri dapat dipahami sebagai upaya 
memberikan atau meningkatkan kekuasaan (power) kepada pihak yang lemah atau kurang beruntung (disadventaged). ${ }^{4}$ Pemberdayaan merupakan upaya untuk membangun eksistensi seseorang dalam kehidupannya dengan memberi dorongan agar memiliki kemampuan ataupun keberdayaan ${ }^{5}$. Pemahaman pemberdayaan ini adalah sebagai cara untuk memberikan kekuatan kepada masyarakat yang mengalami situasi ketidakberdayaan. Ketidakberdayaan dimaksudkan bukan hanya dari segi ekonomi saja, tapi juga ketidakberdayaan dalam menciptakan ideide kreatif, ketidakberdayaan dalam hubungan sosial, dan ketidakberdayaan dalam segi ekologi. Shardlow melihat bahwa berbagai pengertian mengenai pemberdayaan pada intinya membahas bagaimana individu, kelompok ataupun komunitas berusaha mengontrol kehidupan mereka sendiri dan mengusahakan untuk membentuk masa depan sesuai keinginan mereka ${ }^{6}$.

Sementara itu, Ife melihat pemberdayaan secara ringkas sebagai upaya untuk meningkatkan daya (power) dari kelompok yang kurang beruntung (disadvantaged). ${ }^{7}$

Seperti yang telah Shardlow dan Ife kemukakan, pemberdayaan pada hakekatnya adalah untuk meningkatkan kemampuan menuju kemandirian, pemberdayaan menekankan pada pentingnya masyarakat untuk mengorganisir diri mereka sendiri secara mandiri untuk meningkatkan kemampuan. Lebih lanjut Ife berpendapat bahwa "pemberdayaan adalah upaya menyediakan sumber daya, peluang, pengetahuan, dan keterampilan bagi masyarakat untuk meningkatkan kapasitas mereka untuk menentukan masa depan mereka sendiri dan untuk mengambil bagian dan mempengaruhi kehidupan masyarakat". 8

Masyarakat yang dimaksud disini bukan berarti tidak memiliki potensi dan pengetahuan, namun masyarakat belum memiliki kemampuan, pengetahuan, peluang dan keterampilan untuk mengelola potensi yang ada. mereka belum mengetahui potensi-potensi yang ada disekitar mereka atau belum mengetahui potensi-potensi yang ada pada diri mereka sendiri.

\section{Proses Pemberdayaan Masyarakat}

Sebagai suatu proses, pemberdayaan merupakan proses yang berkesinambungan sepanjang hidup seseorang (on going) dan sepanjang komunitas itu masih ingin melakukan perubahan dan perbaikan, dan tidak hanya terpaku pada suatu program saja. Sebagai suatu program,

\footnotetext{
${ }^{4}$ Syamsir Salam dan Amir Fadhilah, Sosiologi Pedesaan, (Jakarta: Lembaga Penelitian UIN Syarif Hidayatullah Jakarta, 2008), h. 232.

5 M Barid Nizarudin Wajdi, "HARMONISASI NILAI PENDIDIKAN ISLAM DENGAN KEARIFAN BUDAYA LOKAL,” Jurnal Studi Islam: Pancawahana 11, no. 1 (2016): 51-78.

${ }^{6}$ Dakwah Kultural, "DAKWAH KULTURAL, KARYA ' ULAMA INDONESIA Kajian Untuk Menangkal Radikalisme Agama Muh. Barid Nizaruddin Wajdi 1,” Lentera 1 (2016): 37-54.

7 Isbandi Rukminto Adi, Intervensi Komunitas \& Pengembangan Masyarakat Sebagai Upaya Pemberdayaan Masyarakat, (Jakarta: Rajawali Pers, 2013), cet. 2, h.206

${ }^{8}$ Salam op. cit., h. 233
} 
pemberdayaan dilihat dari tapahan-tahapan kegiatan guna mencapai suatu tujuan, yang biasanya sudah ditentukan jangka waktunya. ${ }^{9}$

Tahapan pemberdayaan merupakan salah satu langkah dimana lembaga melakukan kegiatan pemberdayaan terhadap komunitas atau masyarakat disekitarnya. Tahapan pemberdayaan masyarakat seperti yang diungkapkan oleh Nana Mintarti yaitu:

a. Penyadaran. Dimana kegiatan penyadaran yang dilakukan meliputi proses pengenalan potensi diri dan lingkungan serta membantu komunitas untuk merefleksikan dan memproyeksikan keadaan dirinya, baik dalam berinteraksi dengan kekuatan-kekuatan domistik maupun kekuatan global dalam bentuk informasi, teknologi, modal sosial, budaya dan peluang politik.

b. Pengorganisasian. Tahapan ini merupakan tahapan dimana suatu organisasi dan kelembagaan harus berawal dari prakasa masyarakat secara sukarela serta diadakannya suatu penguatan organisasi.

c. Kaderisasi. Suatu tahapan dimana suatu organisasi mempersiapkan kader-kader pengembangan keswadayaan lokal yang akan mengambil alih tugas pendampingan setelah program berakhir. Kader-kader dipillih secara partisipatif oleh masyarakat.

d. Dukungan Teknis. Dukungan teknis ini diberikan pada proses produksi yang mencakup dukungan untuk memperbaiki proses atau teknologi yang sedang digunakan.

e. Pengelolaan Sistem. Tahapan dimana organisasi membantu kliennya dalam upaya memperlancar upaya masyarakat memperoleh kebutuhan, baik secara individu maupun kelompok. ${ }^{10}$

Tahapan pemberdayaan ini akan berjalan dengan baik bila adanya dukungan dari pihakpihak internal dan eksternal Karena untuk menciptakan masyarakat yang terbedaya membutuhkan dukungan dari semua pihak.

\section{Strategi Pemberdayaan Masyarakat}

Upaya pemberdayaan masyarakat merupakan tuntutan utama pembangunan, ini terkait dengan teori sumber daya manusia yang memandang mutu penduduk sebagai kunci utama

${ }^{9}$ Isbandi Rukminto Adi, Pemikiran-Pemikiran Dalam Pembangunan Kesejahteraan Sosial, (Jakarta: Lembaga Penerbit FE-UI, 2002), h. 172-171.

10 Siti Habibah, "Pemberdayaan Ekonomi Perempuan Melalui Wirausaha Daur Ulang Sampah Kering di Kelurahan Pasar Minggu", Skripsi pada UIN Syarif Hidayatullah Jakarta, Jakarta, 2009, h.18-19, tidak dipublikasikan. 
pembangunan. ${ }^{11}$ Dalam konteks pekerjaan sosial, pemberdayaan dapat dilakukan melalui tiga aras atau matra pemberdayaan (empowerment setting): mikro, mezzo, dan makro.

a. Aras Mikro

Pemberdayaan dilakukan terhadap klien secara individu melalui bimbingan, konseling, stress management crisis intervention. Tujuan utamanya adalah membimbing atau melatih klien dalam menjalankan tugas-tugas kehidupannya. Model ini sering disebut sebagai pendekatan yang berpusat pada tugas. Pemberdayaan dalam aras mikro ini lebih kepada membimbing dan melatih masyarakat untuk menjalankan tugas-tugas kehidupan.

b. Aras Mezzo

Pemberdayaan dilakukan terhadap sekelompok klien. Pemberdayaan dilakukan dengan menggunakan kelompok sebagai media intervensi. Pendidikan dan pelatihan, dinamika kelompok, biasanya digunakan sebagai strategi dalam meningkatkan kesadaran, pengetahuan, keterampilan, dan sikap-sikap klien agar memiliki kemampuan memecahkan permasalahan yang dihadapinya. Seminar pelatihan dan pendidikan bertujuan agar masyarakat bisa lebih peduli terhadap lingkungan terutama sampah. Selain meningkatkan rasa kepedulian terhadap lingkungan, masyarakat juga dapat memberdayakan diri sendiri dan bahkan juga masyarakat sekitar untuk meningkatkan kreativitas dan perekonomian keluarga.

c. Aras Makro

Pendekatan ini disebut juga sebagai strategi sistem besar, karena sasaran perubahan diarahkan pada sistem lingkungan yang lebih luas. Perumusan kebijakan, perencanaan sosial, kampanye, aksi sosial, lobbying, pengorganisasian masyarakat, manajemen konflik, adalah beberapa strategi dalam pendekatan ini. Strategi sistem besar memandang klien sebagai orang yang memiliki kompetensi untuk memahami situasi-situasi mereka sendiri, dan untuk memilih serta menentukan strategi yang tepat untuk bertindak.

Pendekatan tiga model pemberdayaan ini diharapkan agar masyarakat dapat berdayakan diri sendiri untuk memenuhi kebutuhan sesuai rencana dan langkah yang sudah direncanakan.

\section{B. Prostitusi}

\section{Definisi Pelacuran}

Pelacuran berasal dari bahasa Latin pro-stituere, yang berarti membiarkan diri berbuat zina.

${ }^{11}$ Edi Suharto, Membangun Masyarakat Mamberdayakan Rakyat, (Bandung: PT. Refika Aditama, 2005) h. 66. 
Sedang prostitue adalah pelacur dikenal pula dengan istilah WTS atau wanita tunasusila. Maka pelacur itu adalah wanita yang tidak pantas kelakuannya dan bisa mendatangkan penyakit, baik kepada orang lain yang bergaul dengan dirinya, maupun kepada diri sendiri. Pelacur adalah profesi yang menjual jasa untuk memuaskan kebutuhan seksual pelanggan. Bisaanya pelayanan ini dalam bentuk menyewakan tubuhnya. Dari kedua definisi ini dapat disimpulkan bahwa prostitusi merupakan perzinaan dengan menjual jasa untuk memuaskan kebutuhan seksual berupa menyewakan tubuh. Sehingga prostitusi bersifat negatif dan dapat digolongkan sebagai kejahatan terhadap masyarakat.

a. Prostitusi adalah bentuk penyimpangan seksual, dengan pola-pola organisasi implus/dorongan seks yang tidak wajar dan tidak terintgrasi, dalam bentuk pelampiasan nafsu-nafsu seks tanpa kendali dengan banyak orang (prosmiskuitas), disertai eksploitasi dan komersialisasi seks, yang impersonal tanpa ateksi sifatnya,

b. Pelacur merupakan peristiwa penjualan diri (persundalan) dengan jalan memperjualbelikan badan, kehormatan dan kepribadian kepada banyak orang untuk memuaskan nafsu-nafsu seks, dengan imbalan pembayaran.

c. Pelacuran ialah perbuatan perempuan atau laki-laki yang menyerahkan badanya untuk

d. berbuat cabul secara seksual dengan mendapatkan upah.

\section{Daur Ulang Sampah}

\section{Pengertian Daur Ulang}

Ada beberapa upaya yang dapat dilakukan untuk mengurangi volume sampah, empat (4R) prinsip yang dapat digunakan dalam menangani masalah sampah antara lain sebagai berikut:

a. Reduce (mengurangi), yakni upayakan meminimalisi barang atau material yang kita pergunakan.

b. Reuse (menggunakan kembali), yakni pilihlah barang yang bisa dipakai kembali, hindari pemakaian barang yang sekali pakai (disposable).

c. Recycle (mendaur ulang), yaitu barang yang sudah tidak berguna lagi bisa didaur ulang sehingga bermanfaat serta memiliki nilai tambah. Tidak semua barang bisa didaur ulang, namun saat ini sudah banyak industri formal dan industri rumah tangga yang memanfaatkan sampah menjadi barang yang bermanfaat dan memiliki nilai ekonomis.

d. Replace (mengganti), yakni mengganti barang-barang yang hanya bisa dipakai sekali dengan barang yang lebih tahan lama. Selain itu menggunakan barang-barang yang lebih ramah lingkungan, misalnya mengganti kantong keresek dengan keranjang bila 
berbelanja, dan menghindari penggunaan styrofoam karena kedua bahan ini tidak bisa terdegradasi secara alami. ${ }^{12}$

Pada penelitian ini, penulis membahas mengenai Recycle atau mendaur ulang. Daur ulang adalah proses untuk menjadikan suatu bahan bekas menjadi bahan baru dengan tujuan mencegah adanya sampah yang sebenarnya dapat menjadi sesuatu yang berguna, mengurangi bahan baju yang baru, mengurangi penggunaan energi, mengurang polusi, kerusakan lahan dan emisi gas rumah kaca jika dibandingkan dengan proses pembuatan barang baru.

Daur ulang adalah salah satu strategi pengelolaan sampah padat yang terdiri atas kegiatan pemisahan, pengumpulan, pemrosesan, pendistribusian, dan pembuatan produk atau material bekas pakai dan komponen utama dalam menajemen sampah modern. ${ }^{13}$

Sampah padat dapat di daur ulang dengan cara memisahkan, mengumpulkan, memproses, mendistribusi dan membuatnya menjadi barang-barang yang dapat digunakan kembali. Sampah padat juga menjadi bahan utama dalam proses daur ulang. Sampah dapat mencemari lingkungan dan mambahayakan kesehatan. Sampah juga menyebabkan timbulnya banjir. Akan tetapi, melalui daur ulang, sampah dapat diolah lagi menjadi barang yang berguna. Daur ulang sampah adalah proses pengolahan kembali barang-barang yang tidak berguna menjadi barang yang berguna. ${ }^{14}$

Pendaurulangan sampah di masyarakat dapat dilakukan dalam beberapa cara, antara lain pendaurulangan sampah secara manual dan pendaurulangan dilakukan oleh pabrik. Sampah yang didaur ulang secara manual biasanya berasal dari benda-benda, misalnya plastik, kertas, karton, besi, tembaga, tulang, kaca, dan lain sebagainya. Pendaurulangan yang dilakukan oleh pabrik juga memerlukan bahan baku yang berasal dari plastik, kaca, besi, kertas, tembaga, tulang, tergantung dari hasil produksi dari pabrik yang bersangkutan. ${ }^{15}$

Sampah memiliki jenis yang bermacam-macam, pengolahan terhadap sampah juga bervariasi tergantung dari jenis sampah tersebut. Pengolahan sampah dapat dilakukan secara manual dengan diolah langsung oleh manusia, dan juga dapat diolah oleh pabrik. Sampah yang diolah secara manual biasanya berbentuk kreasi dan produk yang diolah dengan ide-ide kreatif. Sampah yang diolah oleh pabrik biasanya akan menjadi produk yang sama seperti barang yang

${ }^{12}$ Arif Zulkifli, Dasar-Dasar Ilmu Lingkungan, (Jakarta: Salemba Teknika, 2014), h. 106.

13 A. Guruh Permadi, Menyulap Sampah Jadi Rupiah, (Surabaya: Mumtaz Media, 2011), h.35.

${ }^{14}$ Trim Sutidja, Daur Ulang Sampah, (Bumi Aksara, 2001), cet-2, h. 38.

${ }^{15}$ Achmad Serudji Hadi, "Daur Ulang Barang Bekas sebagai Penopang Sumber Kehidupan”, Laporan Penelitian pada Universitas Indonesia Program Pascasarjana Bidang Ilmu Hukum, Jakarta, 2001, h. 28-29. 
telah di daur ulang sebelumnya.

\section{Manfaat Daur Ulang}

Menurut Kamus Besar Bahasa Indonesia (KBBI), manfaat adalah guna, faedah, laba, untung. Arti memanfaatkan adalah "menjadikan ada manfaatnya", sedangkan pemanfaatan adalah "proses, cara, perbuatan memanfaatkan"e 16

Dengan daur ulang, sampah dapur dan sampah pasar dapat diolah menjadi pupuk. Sampah plastik dapat dilebur dan dicetak ulang menjadi alat-alat rumah tangga. Sampah kayu dapat dipakai sebagai bahan untuk membuat kerajinan tangan. Sampah kayu juga dapat digunakan sebagai bahan bakar. Sampah logam atau besi dapat didaur ulang menjadi alat-alat pertanian dan pertukangan. ${ }^{17}$

Sudah pasti daur ulang sampah sangat banyak manfaatnya, karena dengan daur ulang sampahsampah yang ada di lingkungan dapat diminimalisir. Pengelolaan sampah yang baik memberikan dua manfaat penting yaitu:

a. Mengurangi pencemaran lingkungan

b. Pemanfaatan sampah dapat meningkatkan nilai ekonomi atas benda yang bersangkutan, sehingga menguntungkan masyarakat tertentu yang mengelolanya. ${ }^{18}$

\section{METODE PENELITIAN}

\section{A. Jenis Penelitian}

Penelitian ini merupakan penelitian dengan pendekatan metode kualitatif. Pendekatan kualitatif meliputi kelompok fokus, studi kasus penelitian etnografis, dan model penelitian partisipatif. Penelitian kualitatif sendiri didefinisikan sebagai prosedur penelitian yang menghasilkan data deskriptif (berupa kata-kata yang tertulis atau lisan dari orang-orang dan prilaku yang diamati) pendekatan ini diarahkan pada latar belakang individu secara utuh. Selanjutnya penelitian kualitatif ini nantinya akan dilakukan dengan pendekatan studi kasus, karena berangkat dari studi yang mendalam terhadap kasus-kasus tertentu. Sedangkan pada penelitian ini menggunakan pendekatan survey.

\section{B. Lokasi Penelitian}

${ }^{16}$ Kamus Besar Bahasa Indonesia (KBBI) Online, versi 1.3

${ }^{17}$ Trim Sutidja, Daur Ulang Sampah, (Bumi Aksara, 2001), cet. 2, h. 38.

${ }^{18}$ Achmad Serudji Hadi, "Daur Ulang Barang Bekas sebagai Penopang Sumber Kehidupan”, Laporan Penelitian pada Universitas Indonesia Program Pascasarjana Bidang Ilmu Hukum, Jakarta, 2001, h. 64. 
Penelitian ini dilakukan di Eks Lokalisasi Padang Pasir desa Karangbendo Kecamatan Rogojampi Kabupaten Banyuwangi.

\section{Teknik Pengumpulan Data}

Guna menjaring data, penelitian dilakukan dengan menggunakan tiga pendekatan yaitu: (1) wawancara mendalam (indept interview), (2) pengamatan peran (Participan Observation) serta (3) Dokumentasi (Documentation).

\section{Sumber Data Dan Penentuan Informan}

Dalam penelitian ini penentuan informan pertama diambil dengan menggunakan sampling porposife dimana sampel diambil bukan tergantung pada populasi, melainkan sesuai dengan tujuan penelitian.

\section{Teknik Analisa Data}

Teknik analisis data yang dipergunakan dalam penelitian ini dengan metode campuran untuk kualitatif adalah dengan interaktif model, yang terdiri dari tiga komponen yaitu: reduksi data (data reduction), penyajian data (data display) penarikan serta pengujian data (drowing and ferivying conclution) (Miles And Huberman dalam Pawito, 2008: 104).

Selanjutnya untuk melakukan pemberdayaan langsung pada komunitas dapat menggunakan metode RRA (Rapid Rural Appraisal) merupakan metode penilaian keadaan secara cepat, yang dalam praktek, kegiatan RRA lebih banyak dilakukan komunitas oleh "orang luar" dengan tanpa atau sedikit melibatkan masyarakat setempat. Meskipun sering dikatakan sebagai teknik penelitian yang "cepat dan kasar/kotor" tetapi RRA dinilai masih lebih baik dibanding teknik-teknik kuantitatif klasik.

Metode RRA memiliki tiga konsep dasar yaitu; (a) perspektif sistem, (b) triangulasi dari pengumpulan data, dan (c) pengumpulan data dan analisis secara berulang-ulang (iterative).

\section{TEMUAN LAPANGAN}

\section{A. Gambaran umum ekslokalisasi Padang Pasir.}

Ekslokalisasi Padang Pasir berada di Dusun Pancoran Desa Karangbendo Kecamatan Rogojampi Kabupaten Banyuwangi. Pada dusun pancoran jumlah total penduduk adalah 1554 orang dengan jumlah penduduk laki-laki 552 orang, jumlah penduduk perempuan 502 dan jumlah total 302 KK. Namun masih memiliki 148 Rumah Tangga Miskin.

Ekslokalisasi Padang Pasir dusun Pancoran Kecamatan Rogojampi yang terletak di pingir jalan raya menuju pemandian Pancoran, sekilas tidak nampak perkampungan tersebut merupakan ekslokalisasi karena yang terlihat hanya rumah-rumah di pinggir jalan raya dan ada 
yang masuk di gang-gang.

\section{Gambar 3: Ekslokalisasi Padang Pasir}

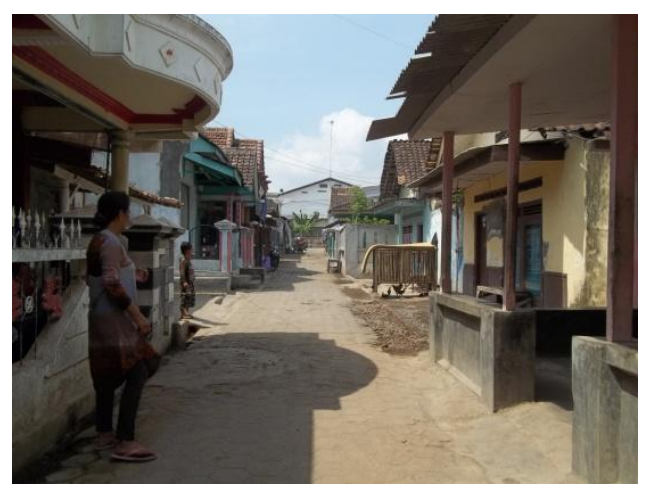

Lengang : Semenjak lokalisasi di tutup aktifitas prostitusi terhenti, tidak ada pengunjung, pada akhirnya para mucikari kehilangan penghasilan.

Di ekslokalisasi Padang Pasir bertemu dengan Bapak Samsuri 36 tahun yang hanya lulusan SD. Bapak samsuri merupakan cucu dari Bapak yakin yang berasal dari Gurit, dan bapak yakin inilah yang merupakan cikal bakal adanya lokalisasi di padang pasir. Pada tahun 1971 bapak Yakin yang berasal dari Gurit datang ke Pancoran untuk membuka usaha warung, dari warung yang ada dia juga menyediakan jasa PSK yang pada awalnya hanya 1 orang saja. Dan seiring berjalannya waktu lokasi dimana warung itu berada mulai dikenal sebagai lokalisasi yang dikenal dengan padang pasir dan dihuni $36 \mathrm{KK}$ pada saat lokalisasi tersebut masih ramai dan saat ini KK yang tinggal di ekslokalisasi padang pasir tinggal $26 \mathrm{KK}$ yang merupakan anak cucu keturunan dari bapak Yakin namun tidak semua KK yang ada di lokalisasi padang pasir menjadi mucikari. Sebelum lokalisasi di tutup, memiliki 20 s/d 30 PSK dan saat masih ramai tariff yang ada adalah Rp.40.000,-, dengan bagi hasil Rp.10.000, untuk mucikari dan PSK mendapat jatah makan dari mucikari. Akan tetapi, jika kondisi lokalisasi sedang sepi tarif PSK/WPS/PS di eks lokalisasi ini, relatif lebih murah dengan dibanding dengan lokalisasi yang lain yaitu kisaran 1025 ribu rupiah. Hal ini banyak dilatarbelakangi oleh usianya yang rata-rata di atas 35 tahun. PSK dilokalisasi padang pasir banyak yang berasal dari Jember dengan rata-rata usia diatas 35 tahun s/d 50 tahun dan berstatus janda. Saat ini setelah lokalisasi resmi dihentikan aktifitas prostitusinya para PSK pergi keluar pulau, ada yang ke Bali, Kalimantan, Sulawesi dan Papua. Namun secara sembunyi-sembunyi masih ada saja PSK yang datang, menetap sementara waktu, dan kemudian pergi ketempat lain, karena menghindari razia dari satpol PP yang masih rajin menyambangi ekslokalisasi tersebut. Sedangkan para mantan mucikari yang masih tinggal di ekslokalisasi padang pasir saat ini sudah berpindah profesi menjadi pemilah barang 
rongsokan milik orang lain yang memiliki modal besar untuk mampu mendatangkan barang rongsokan dari Bali, dengan upah harian berkisar antara Rp.15.000,- s/d Rp.20.000,-. Selain itu mantan mucikari ada yang menjadi satpam ataupun buruh di gudang tembakau yang masih baru didirikan selama 2 bulan ini. Menurut pengakuan dari ibu siti 42 tahun, yang mantan mucikari berpendidikan lulusan SMP setelah penutupan lokalisasi banyak mantan mucikari yang mengalami stress karena selama ini mereka telah terlanjur mengambil kredit sepeda motor dan setelah lokalisasi di tutup praktis penghasilan mereka menurun drastis, dan hampir tidak ada sama sekali. Selama ini lokalisasi padang pasir belum pernah mendapatkan bantuan ataupun pelatihan ketrampilan. Penutupan lokalisasi sebenarnya secara terpaksa disetujui oleh bapak samsuri dan ibu siti, karena menurut mereka dengan adanya penutupan lokalisasi secara tidak langsung memaksa mereka untuk bertahan hidup dengan mencari pekerjaan yang lebih baik dari pada menjadi mucikari.

\section{B. Strategi Yang Dilakukan Untuk Mencapai Kondisi Harapan}

Mengacu pada pendapat yang disampaikan oleh Edi Suharto, dalam bukunya yang berjudul, Membangun Masyarakat dan Mamberdayakan Rakyat, maka strategi yang dapat dilakukan dalam proses pemberdayaan mantan mucikari yang berada di ekslokalisasi Padang Pasir adalah strategi Aras Mezzo dimana pada pemberdayaan tersebut dilakukan terhadap sekelompok klien. Pemberdayaan dilakukan dengan menggunakan kelompok sebagai media intervensi. Pendidikan dan pelatihan, dinamika kelompok, biasanya digunakan sebagai strategi dalam meningkatkan kesadaran, pengetahuan, keterampilan, dan sikap-sikap klien agar memiliki kemampuan memecahkan permasalahan yang dihadapinya. Seminar pelatihan dan pendidikan bertujuan agar masyarakat bisa lebih peduli terhadap lingkungan terutama sampah. Selain meningkatkan rasa kepedulian terhadap lingkungan, masyarakat juga dapat memberdayakan diri sendiri dan bahkan juga masyarakat sekitar untuk meningkatkan kreativitas dan perekonomian keluarga. Untuk menuju hal tersebut maka hal-hal yang perlu dilakukan adalah :

\section{Fokus Permasalahan}

Permasalahan yang terjadi desa Karangbendo sebenarnya pada sektor perekonomian, dimana dengan akar permasalah kemiskinan memunculkan begitu banyak permasalahan yang mengikutinya. Dengan kemiskinan menyebabkan berbagai problem kemasyarakatan yang urgent untuk bisa diselesaikan seperti, dari sector kesehatan masih adanya rumah yang tidak sehat karena tidak memiliki jamban dengan jumlah 755 Buah. Masih ada beberapa Sarana dan prasarana seperti fasilitas jalan, sebagai jalur distribusi perekonomian belum terbangun dan tertata dengan baik. 
Termasuk dengan adanya lokalisasi di dusun Poncoran yang terkenal dengan nama Lokalisasi Padang Pasir, ini merupakan dampak dari kemiskinan. Dari data yang didapat jumlah total rumah tangga miskin yang ada di desa Karangbendo adalah 649. Seperti yang tergambar pada table dibawah :

Tabel 4.6

Rumah Tangga Miskin

\begin{tabular}{|c|c|c|r|}
\hline No. & Dusun & RTM & Prosentase \\
\hline 1 & Krajan & 71 & $11.00 \%$ \\
\hline 2 & Karanganyar & 143 & $22.00 \%$ \\
\hline 3 & Bades & 163 & $25.00 \%$ \\
\hline 4 & Jajangsurat & 124 & $19.00 \%$ \\
\hline 5 & Pancoran & 148 & $23.00 \%$ \\
\hline & Jumlah & $\mathbf{6 4 9}$ & $100.00 \%$ \\
\hline
\end{tabular}

Sumber : Profil Desa Karangbendo, 2015

Dari tabel yang ada diatas dapat dijelaskan bahwa, desa Karangbendo memiliki jumlah total 649 Rumah Tangga Miskin (RTM) dengan rincian sebagai berikut : Posisi dusun yang memiliki jumlah RTM tertinggi adalah Bades dengan 163 RTM, prosentase 25\%. Pancoran 23\% dengan jumlah 148 RTM. Karanganyar 22\% dengan 143 RTM. Jajangsurat 19\% dengan jumlah

124 RTM dan Krajan 11\% dengan jumlah 71 RTM.

Kemiskinan telah membuat orang dapat melakukan apa saja, dengan kata lain segala sesuatu akan dilakukan untuk memenuhi kebutuhan hidupnya. Termasuk menjadi mucikari. Seperti mucikari yang tinggal di lokalisasi Padang Pasir dusun Pancoran desa Karangbendo dan saat ini mereka berjumlah 26 orang. Dan pada kenyataannya sesuai dengan survey yang lelah dilakukan pada lokalisasi Padang Pasir kecamatan Rogojampi, belum pernah pendapatkan bantuan berupa dana maupun pelatihan yang telah diprogramkan oleh pemerintah daerah kabupaten Banyuwangi. Setelah penutupan lokalisasi mantan mucikari yang berada di eks lokalisasi padang pasir tidak mampu lagi berpenghasilan seperti sebelum penutupan lokalisasi. Namun kehidupan membutuhkan biaya untuk mampu bertahan, pada akhirnya sebagian dari mantan mucikari mulai beralih profesi, ada yang mencoba untuk 
berdagang, mengumpulkan sampah dan menjadi buruh pemilah sampah. Pemberdayaan mantan mucikari melalui pemanfaatan sampah organik dan nonorganik pada ekslokalisasi padang pasir rogojampi Banyuwangi, karena dengan hal ini diharapkan para mantan mucikari akan mampu berdaya dan dapatkan penghasilan untuk memenuhi kebutuhannya serta selanjutnya beralih profesi.

\section{Strategi Pemecahan Masalah}

\section{a. Strategi yang Dilakukan Untuk Mencapai Kondisi Harapan}

Pengabdian ini bersifat pemberdayaan secara 'riil' kepada mantan mucikari yang berada di eks lokalisasi Padang Pasir dengan memberdayaan pemanfaatan sampah. Adapun strategi yang akan dilakukan adalah sebagai berikut:

\section{Pendataan mantan mucikari;}

Pendataan ini diperlukan untuk menseleksi mantan mucikari yang sangat membutuhkan pemberdayaan, sehingga pengabdian ini tepat sasaran dan dapat dilaksanakan secara maksimal sehingga memberikan kontribusi yang nyata bagi mantan mucikari supaya berdaya.

Dari pendataan yang didapat, mantan mucikari yang masih tinggal di Ekslokalisasi Padang Pasir berjumlah $26 \mathrm{KK}$ yang diketuai oleh Bapak Miswan Untung sebagai ketua RT.

\section{Pelatihan tentang cara pemanfaatan sampah bekerja sama dengan stakeholders;}

Pelatihan pemanfatan sampah organic dan non organic. Sampah organic dapat dimanfaatkan dengan diolah menjadi pupuk sedangkan sampah non arganic dapat dimanfaatkan untuk kerajinan tangan seperti sampah bungkus kopi dapat dimanfaatkan menjadi tas, atau sampah minuman gelasan juga dapat dimanfaatkan untuk tas.

Pelatihan pemanfaatan sampah bekerjasama dengan LSM Merdeka dari sampah Banyuwangi. Pemateri untuk mengolahan sampah organic menjadi pupuk organic adalah Bapak Ramang Raka Siwi sedangkan pemateri untuk pengolahan sampah plastik adalah Ibu Dian Aksi.

\section{Persiapan untuk aplikasi dari pelatihan ;}

1. Mempersiapkan tempat untuk proses penyampaian materi. Tempat yang dipilih adalah tempat yang representative, berada di lokasi yang mudah dijangkau oleh masyarakat, namun tempat tersebut harus membuat nyaman peserta, bukan di tempat terbuka, karena pesertanya adalah para mantan mucikari. 
2. Mengumpulkan bahan untuk pelatihan. Bahan yang dibutuhkan untuk pelatihan selain sampah adalah peralatan menjahit yang dapat dibeli di toko-toko alat penjahait. Selanjutnyan mengumpulkan sampah-sampah yang diperlukan, sampah organic dan sampah non organic. Dikarenakan bahan baku harus disediakan dengan banyak dalam waktu singkat maka bahan baku harus membeli kepengepul.

3. Memilah sampah dari sampah organic dan sampah non organic. Sampah organic yang disiapkan adalah sampah sisa dapur rumah tangga. Dan sampah yang non organic adalah sampah bungkus kopi, sampah bungkus sabun cuci, dan sampah bekas tempat air minuman kemasan yang gelasan

4. Dan melakukan pelatihan.

\section{Pelaksanaan Pengabdian}

Pemberdayaan Mantan Mucikari Melalui Pemanfaatan Sampah Organik dan Non Organik pada EksLokalisasi Padang Pasir Pancoran Rogojampi Banyuwangi telah dilaksanakan di sekitar Eks Lokalisasi Padang Pasir yang berada di dusun Pancoran Desa Karang Bendo Kecamatan Rogojampi Kabupaten Banyuwangi.

Pemberdayaan tersebut dilaksanakan dalam bentuk pelatihan yang dilakukan satu hari dengan dua kali sesi. Sesi pertama adalah pelatihan pembuatan kompos dari sampah dapur yang dilaksanakan pada jam 09.00 wib sampai dengan jam 11.00 wib. Dan yang kedua adalah pelatihan pengolahan sampah plastik dilakukan pada jam 11.30 wib sampai dengan jam 14.00 wib.

Pada pelatihan tersebut yang hadir sejumlah 33 peserta dengan dihadiri oleh peserta manta mucikari, masyarakat sekitar, perangkat pemerintah desa, perangkat pemerintah kecamatan serta perwakilan dari BPMPD kabupaten Banyuwangi.
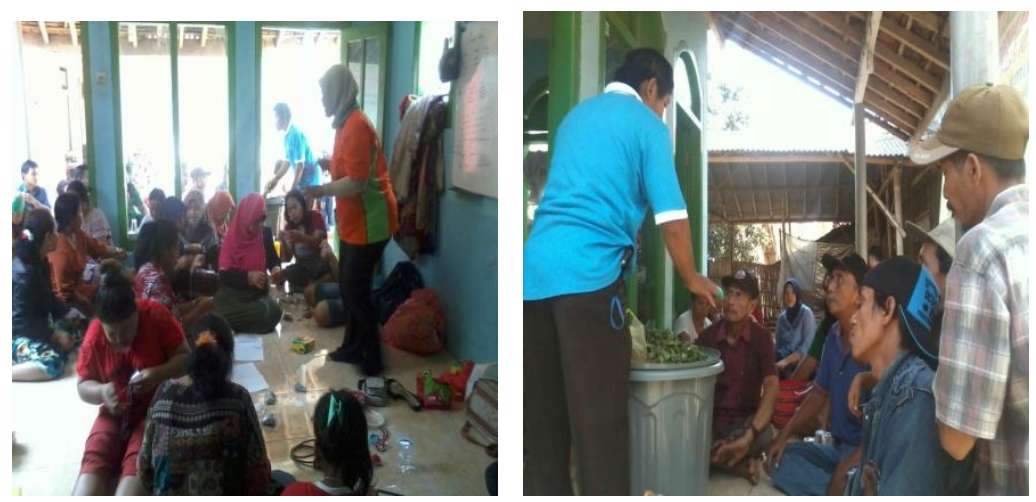

Gambar 7: Pelatihan pemanfaatan sampah organic dan non organik. 
Serius : Peserta pelatihan serius mengikuti presentasi dari pemateri yang disampaikan oleb Bapak. Ramang dan Ibu Dian dari LSM Merdeka dari sampab Banyuwangi.

\section{Proses pembuatan kerajinan dari sampah organik dan non organik ;}

Pada pelatihan pemanfaatan sampah non organic, pemateri memberi pengetahuan pada masyarakat dengan membuat tas, bros dan gantungan kunci.

\section{a. Tas dari bungkus kopi}

1) Untuk membuat tas bahan yang dibutuhkan adalah:

Gunting 1 buah, Cutter 1 buah, Bungkus kopi bekas 500 biji, Kain perca.

2) Dalam proses pembuatan tas yang berasal dari sampah non organic sebenarnya sangat bermacam-macam serta bervariasi dan salah satu contoh pemanfaatan sampah dapat dibuat tas seperti berikut:

Pertama: Siapkan satu bekas bungkus kopi instan merek apa saja. Potong menjadi dua bagian selebar $4 \mathrm{~cm}$.

Ke dua: Potongan bekas bungkus kopi selebar $4 \mathrm{~cm}$ tersebut di lipat ke arah dalam sepanjang $1 \mathrm{~cm}$ di kedua sisinya sehingga menghasilkan pita plastik selebar $2 \mathrm{~cm}$. Buat pita seperti ini sebanyak minimal 1000 buah dari 500 bungkus bekas kopi instan.

Ke tiga: Ambil 4 buah pita dan anyam seperti membuat baling-baling. Ke empat: Pada baling-baling yang sudah terbentuk selanjutnya tambahkan pita lainnya satupersatu dan jangan lupa membuat sudut tegak vertikal agar bisa dianyam ke arah atas. Bila proses ini diabaikan maka anyaman hanya akan berbentuk seperti tikar saja dan tidak berupa keranjang. Atur lebar dan tinggi anyaman sesuai kebutuhan.

Ke lima: Setelah keranjang atau tas cantik Anda selesai, bagian dalam tas dapat ada beri lapis dari kain perca agar tidak bolong-bolong atau biarkan seperti itu supaya tetap orsinil dan antik.
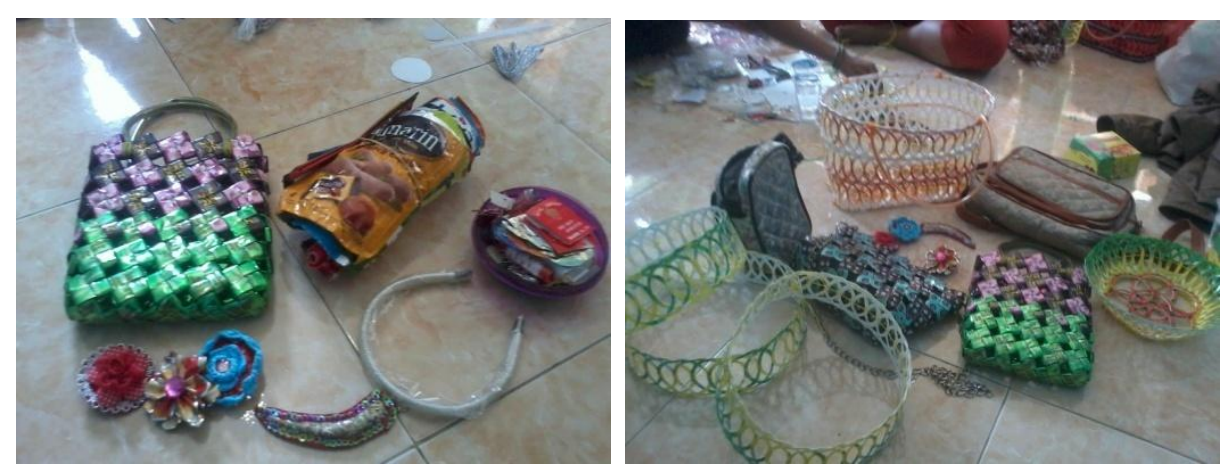

Volume 1, Number 1, Mei 2017| 43

Pemberdayaan Mantan Mucikari melalui Pemanfaatan Sampah Organik dan Non Organik pada Eks 
Gambar 8. Barang-barang cantik ini dibuat dari pemanfaatan sampah plastik dari hasil Pelatiban.

\section{b. Tas dari bekas tempat air minum gelasan}

Untuk membuat tas bahan yang dibutuhkan adalah :

Gunting 1 buah, Cutter 1 buah, Gelang plastik yang berasal dari bekas tempat minum air gelasan 131 biji, Selang kecil, Tampar kecil, Kain perca

Dalam proses pembuatan tas yang berasal dari sampah non organic dari bekas tempat air minum gelasan dapat dibuat tas seperti berikut :

Pertama: Siapkan satu bekas tempat air minum gelasan merek apa saja. Potong, ambil gelangan yang bagian atasnya saja.

Ke dua: Ambil 3 gelang plastik rangkai dengan dibantu tampar, disambung s/d 40 biji. Ulangi proses ke dua dengan menyambung gelang plastic sampai 37 biji. Buat lagi rangkaian sampai 34 biji dari masing-masingnya di buat lingkaran. Dan buat rangkaian 10 biji 2 buah biarkan lepas. (nantinya akan dibuat alas dari tas)

Ke tiga: Selanjutnya menyambung rangkaian 40,37,dan 34 biji dalam satu rangkaian menyambung kesamping.

Ke empat: Selanjutnya menyambung 2 rangkaian yang 10 biji disambung menyamping.

Ke lima: Susun dan Sambung rangkaian 40,37 dan 34 bersama 2 rangkaian 10 biji menjadi tas keranjang.

Ke enam: Setelah keranjang atau tas cantik Anda selesai, bagian dalam tas dapat ada beri lapis dari kain perca agar tidak bolong-bolong atau biarkan seperti itu supaya tetap orsinil dan antik.

\section{c. Proses Pembuatan Kompos Dari Sampah Organik}

Proses pembuatan pupuk kompos sangat bervariasi. Dan salah satu contoh pembuatan pupuk kompos adalah :

Wadah yang cukup besar seperti pot besar, ember atau bila ada gunakan pekarangan yang cukup luas. Gali lobang kira-kira sedalam 30 - $50 \mathrm{~cm}$ dengan diameter kira-kira lubang 50 cm. Tanah yang dimasukkan dalam karung. Sekop/sendok semen juga bisa Sampah organik dari sisa sayuran, kulit buah, dan sisa-sisa makanan.

Setiap hari sampah-sampah sayuran dan kulit-kulit buah dan juga daun-daunan rontok dari kebun dimasukkan ke dalam lubang atau wadah yang sudah disediakan, kemudian ditutup dengan tanah. Apabila jumlah sampahnya banyak, masukkan sedikit demi sedikit lalu tutup dengan tanah tipis-tipis saja. Masukkan lagi sampahnya, kemudian timbun 
tanah lagi. Begitu setiap hari sampai lubang penuh. Tunggu kira-kira 3 minggu sampah yang ditanam sudah berubah menjadi kompos dan siap dipakai. Pindahkan ke dalam karung bila belum ingin dipakai. Bisa juga langsung diaplikasikan ke tanaman yang ingin diberi pupuk.

Pada pelatihan, proses pembuatan kompos dari sampah rumah tangga yang diajarkan dikarenakan akan mudah untuk buat bagi keluarga. Proses pembuatan kompos pada dasarnya sama dengan pembuatan kompos dari dari dedaunan kering yang ditimbun, namun dapat menggunakan bak air.

\section{Pendampingan dan evaluasi indikator keberhasilan dalam pemberdayaan tersebut;}

Setelah pelatihan dan aplikasi maka diharapkan para mantan mucikari akan mampu memanfaatkan sampah sebagai salah satu sumber penghasilan dan mampu mengubah profesi dengan berdagang dari hasil pemanfaatan sampah. Untuk kelancaran pemasaran dari hasil sampah akan di dampingi untuk pemasarkan dengan menghubungkan dengan kelompok masyarakat, ataupun LSM yang bersedia untuk memasarkan produk hasil pemanfaatan sampah.

\section{Pihak-Pihak Yang Terlibat (Stakeholders) Dan Bentuk Keterlibatannya.}

\section{Badan Pemberdayaan Masyarakat dan Pemerintahan Desa (BPM PD) Kabupaten} Banyuwangi

Badan Pemberdayaan Masyarakat dan Pemerintahan Desa (BPM-PD) Kabupaten Banyuwangi bertugas memberikan pemberdayaan kepada masyarakat terkait bagaimana membina mucikari di eks lokalisasi. BPMPD juga dilibatkan pada waktu pelatihan. Hal ini bertujuan agar menjadi bahan evaluasi BPM-PD dalam memberdayakan mantan mucikari melalui kegiatan/pelatihan yang bersifat ekonomis dan harus berkelanjutan supaya terjadi keseriusan dari berbagai pihak untuk andil dalam mengentaskan masalah prostitusi di kabupaten Banyuwangi terutama di Ekslokalisasi Padang Pasir desa Karangbendo Kecamatan Rogojampi.

\section{LSM Merdeka dari Sampah Banyuwangi}

Pimpinan LSM Merdeka Dari Sampah Ramang Rameli Rakasiwi dan Ibu Dian Aksi sebagai narasumber terkait pengolahan/pemanfaatan sampah organik dan non organik yang benar. Materi disampaikan dalam suatu pertemuan sebelum praktik/pelatihan dilaksanakan. Narasumber bertugas memberikan pencerahan bagaimana proses mengolah sampah yang baik, sehat, dan menguntungkan. 


\section{Camat Kecamatan Rogojampi}

Bapak camat ikut serta dalam pemantauan proses pemberdayaan dan keberlanjutan dari pelatihan pengolahan sampah ini. Diharapkan dengan pemantauan dari pemangku kebijakan, maka dapat diketahui sejauh mana indikator keberhasilan dari pemberdayaan ini.

\section{Kepala Desa Karangbendo}

Bapak Kepala Desa Karangbendo sebagai pemangku kebijakan di kawasan yang ditempati untuk pemberdayaan memiliki peran mengevaluasi indikator perubahan mucikari yang diberdayaan dalam jangka panjang, dan meneruskan program tersebut.

\section{PENUTUP}

\section{A. Kesimpulan}

Setelah penutupan lokalisasi mantan mucikari yang berada di eks lokalisasi padang pasir Rogojampi tidak mampu lagi berpenghasilan seperti sebelum penutupan lokalisasi. Pada akhirnya sebagian dari mantan mucikari mulai beralih profesi, ada yang mencoba untuk berdagang, mengumpulkan sampah dan menjadi buruh pemilah sampah. Dikarenakan disekitar lokalisasi banyak masyarakat yang menjadi pengumpul sampah maka untuk menambah nilai sampah perlu dilakukan pemberdayaan mantan mucikari melalui pemanfaatan sampah organik dan non organik pada eks lokalisasi Padang Pasir Rogojampi Banyuwangi sebagai upaya untuk meningkatkan penghasilan mantan mucikari yang telah mengalami penurunan penghasilan setelah penutupan lokalisasi.

Strategi yang dilakukan untuk pemberdayaan mantan mucikari melalui pemanfaatan sampah organik dan non organik pada eks lokalisasi Padang Pasir Rogojampi Banyuwangi adalah dengan melakukan pelatihan pembuatan kompos dari sampah organik dan membuat tas, bros, dan gantungan kunci dari sampah non organik.

Stakeholder yang terlibat dalam pemberdayaan mantan mucikari melalui pemanfaatan sampah organik dan non organik pada eks lokalisasi Padang Pasir Rogojampi Banyuwangi adalah Perangkat desa Karangbendo, perangkat kecamatan Rogojampi dan BPM PD kabupaten Banyuwangi.

\section{DAFTAR PUSTAKA}

Bappeda, 2014, Pedoman Penulisan Proposal Penelitian Kerjasama Bappeda Kabupaten 
Banyuwangi Dengan Perguruan Tinggi Di Kabupaten Banyuwangi.

Hadi, Achmad Serudji. "Daur Ulang Barang Bekas sebagai Penopang Sumber Kehidupan",

Jurnal Ilmiah Program Pascasarjana Bidang Ilmu Hukum, Jakarta: Universitas Indonesia, 2001.

Kamus Besar Bahasa Indonesia (KBBI) Online, versi 1.3

Inayah, Nurul, SE.,M.Si, 2011, Fungsi dan Peran Perempuan Migran dalam Hubungan Kekeluargaan di Desa Karangdoro, Penelitian Individu, Banyuwangi.

Permadi, A. Guruh, Menyulap Sampah Jadi Rupiah, Surabaya: Mumtaz Media, 2011. Pawito, Ph.D., 2008, Penelitian Komunikasi Kualitatif, Cet. Ke - Pertama, Lkis, Jogjakarta.

Peraturan Bupati Banyuwangi Nomor 88 Tahun 2011, Tentang Pencegahan Dan Penanggulangan Penyebarluasan Pekerja Seks Komersial (PSK) Di Kabupaten Banyuwangi.

Salam, Syamsir. dan Fadhilah, Amir, Sosiologi Pedesaan, Jakarta: Lembaga Penelitian UIN Syarif Hidayatullah Jakarta, 2008.

Siti Habibah. "Pemberdayaan Ekonomi Perempuan Melaluui Wirausaha Daur Ulang Sampah Kering Di Kelurahan Pasar Minggu”, Skripsi pada UIN Syarif Hidayatullah Jakarta: 2009. tidak dipublikasikan.

Suar, Etrizal. "Pengaruh Sampah Plastik Terhadap Pengelolaan Lingkungan Hidup di DKI Jakarta", Jurnal Ilmiah Program Pascasarjana Bidang Ilmu Hukum, Jakarta: Universitas Indonesia, 1996.

Suharto, Edi, Membangun Masyarakat Memberdayakan Rakyat, Bandung: PT. Refika Aditama, 2005.

Sutidja, Trim, Daur Ulang Sampah, Bumi Aksara, cet-2, 2001.

Ulum, Misbahul, dkk, Pengertian Sampah, Yogyakarta: Fakultas Dakwah UIN Sunan Kalijaga Yogyakarta bekerjasama dengan IISEP-CIDA, 2007.

Yudo Prasetyo, 2013, Efektifitas Peraturan Bupati No. 88 Tahun 2011 Implikasinya Terhadap

Pencegahan Dan Penanggulangan Penyebarluasan Pekerja Seks Komersial (Psk) Di Kabupaten Banyuwangi”, Skripsi, UNTAG Banyuwangi

Kultural, Dakwah. "DAKWAH KULTURAL, KARYA “ ULAMA INDONESIA Kajian Untuk Menangkal Radikalisme Agama Muh. Barid Nizaruddin Wajdi 1.” Lentera 1 (2016): 37-54. Wajdi, M Barid Nizarudin. "HARMONISASI NILAI PENDIDIKAN ISLAM DENGAN KEARIFAN BUDAYA LOKAL.” Jurnal Studi Islam: Pancawahana 11, no. 1 (2016): 51-78. 